DOI : https://10.24260/khatulistiwa.v9i2.1478

\title{
CHANGE AND DEVELOPMENT IN NYADRAN RITUAL TRADITION IN YOGYAKARTA
}

\author{
Benny Baskara,Halu Oleo University, Kendari \\ benbasku@gmail.com \\ Vincamira Tasha F, Gadjah Mada University, Yogyakarta \\ tashaflorika379@gmail.com \\ Ali Akbar Muhammad, Gadjah Mada University \\ aliakbarmuhammad1998@gmail.com
}

\section{HIGHLIGHTS}

- The essential element of the nyadran ritual is visiting the graveyard to clean up the grave and praying for the ancestors buried in the grave.

\section{ARTICLE HISTORY}

$\begin{array}{lll}\begin{array}{l}\text { Submit } \\ \text { Revision }\end{array} & : & \text { 10 June } 2019 \\ \begin{array}{l}\text { Revision } \\ \text { Minor }\end{array} & : & 20 \text { July } 2019 \\ \begin{array}{l}\text { Accepted } \\ \text { Published }\end{array} & : & \text { 2019 } \\ & \text { 20 Sept } 2019 \\ & & \end{array}$

\begin{abstract}
The nyadran ritual is a ritual usually conducted by Javanese Muslim to welcome Ramadhan or fasting month in the Islamic calendar. The essential element of the nyadran ritual is visiting the graveyard to clean up the grave and praying for the ancestors buried in the grave. However, in recent development, it seems that change and development are already happened to the nyadran ritual in some of its elements, such as reciting prayer together, parading the offerings to the graveyard, and end up with communal feast. The media construction is also influential, with the coverage of the nyadran ritual in Makam Sewu by various media, such as television, print media, and online media.
\end{abstract}

Keywords; Nyadran ritual, Commodification, Yogyakarta

Copyright@2019 The Authors. Published by The Institute for Research and Community Service Pontianak State Institute for Islamic Studies This is an Open Access article under of CC BY-NC-ND 4.0 License https://creativecommons.org/licenses/by-nc-nd/4.0

KHATULISTIWA: Journal of Islamic Studies Vol. 9. No. 2 September 2019
DOI: https://10.24260/khatulistiwa.v9i2.1478

Change and Development in Nyadran Ritual Tradition in Yogyakarta 


\section{A. INTRODUCTION}

The nyadran ritual is the annual ritual that usually conducted by Javanese Muslim to welcome the coming of Ramadhan or fasting month in the Islamic calendar or Hijri calendar. The nyadran ritual can be conducted personally or individually, or can be conducted communally, usually conducted in the certain community such as in village or sub-village community. The most essential element of the nyadran ritual is visiting the graveyard in order to clean up the grave and praying for the ancestors who were already dead and buried in the grave. However, in its development, it seems that change and development were already happened to the nyadran ritual in some of its elements, such as reciting prayer together, parading the offerings to the graveyard with all equipments and conducted a la royal Javanese manner, and finally end up with communal feast.

One type of change and development is commodification, which actually were already happened to culture and religion in various places around the world. One of its examples is commodification in Islam, where many accessories and merchandise with Islamic symbols are best seller commodities in Indonesia (Fealy, 2008). In many occasions, commodification is usually in line with and done for the sake of tourism, as pointed out by Shepherd (2002), with the support of real case studies, such as the commodification of the performance of the bamboo-beating dance in Hainan, China (Xie, 2003) and in Mardi Gras festival in New Orleans, USA (Gotham, 2002). Because of the impact of tourism, commodification even happened to the greatest ritual of the Bajo people in Wakatobi Islands (Baskara, 2012). In the middle of many research on change and development in traditions, therefore this paper is expected to contribute to the research and study of this field, to enrich the treasury source in this field by focusing to describe the process of change and development in the nyadran ritual in Yogyakarta, Indonesia.

Based on the background above, therefore this paper wants to describe and to compare the performance of the nyadran ritual in two places in Yogyakarta, which are Makam Sewu and Imogiri. This paper also wants to describe the recent performance of the nyadran ritual that already change and developed, and the performance of the nyadran ritual in the past before change and development occurred.

KHATULISTIWA: Journal of Islamic Studies Vol. 9. No. 2 September 2019
DOI: https://10.24260/khatulistiwa.v9i2.1478

Change and Development in Nyadran Ritual Tradition in Yogyakarta 
This paper also analyze how the process of change and development happened to the nyadran ritual, what factors are important and influential as causes and triggers to the change and development of the nyadran ritual, and who are the actors and their roles in the process of the change and development of the nyadran ritual. This paper also wants to examine the assumption that the change and development in the nyadran ritual occurred because of three main factors, which are social transformation, social invention, and media construction, especially in Makam Sewu and Imogiri, the locations where this research is conducted.

The nyadran ritual is deeply rooted in Javanese tradition, even before Islam entered Java or Nusantara archipelago. The root of the word "nyadran" is "sadran" or "sadranan", which is strongly assumed derived from Sanskrit word "sraddha" (Kusumawati, 2013; Purwaningsih, 2017). The word "sraddha" itself means "faith" or "belief", which in its operational definition, "sraddha" means a ritual as a manifestation of faith or belief to send prayer for the ancestors (Purwaningsih, 2017). In Hindu tradition, sraddha itself is a ritual to worship and to eulogize the ancestors, which is even stated in Veda scripture (Mertamupu, 2012). Based on this fact, it can be inferred that the nyadran ritual is a form of religious syncretism, or furthermore, the nyadran ritual is a form of religious symbiosis (Pieris, 1988), which developed in Javanese tradition.

In the beginning, the sraddha ritual is developed in Hindu Javanese society, which happened before the $13^{\text {th }}$ century. When most of the Javanese society was converted to Islam after the $13^{\text {th }}$ century, the old traditions as the legacy of their ancestors were not abandoned and abolished completely. Otherwise, the old traditions that already rooted in their way of life are still kept, retained, and maintained, with some adjustments, modifications, and adaptations, to the changing and developing situations and conditions. This is precisely what happened to the nyadran ritual. It was the sraddha ritual as it is beginning in the Hindu Javanese society before Islam come and entered to Java. After Islam was come and finally embraced by most of Javanese, the name of this ritual is modified and adjusted according to Islamic teachings and values to be sadran, sadranan, or nyadran.

Ritual itself is generally assumed as a thing that never or almost never changed, endured for long time, and become a standard or reference in the certain community. However, in fact, ritual itself is also subject to change (Bell, 1997: 210).

KHATULISTIWA: Journal of Islamic Studies

Vol. 9. No. 2 September 2019
DOI: https://10.24260/khatulistiwa.v9i2.1478

Change and Development in Nyadran Ritual Tradition in Yogyakarta 
Ritual itself is defined in three aspects: (1) it is a physical expression of ideas or beliefs, (2) it is a structural mechanism to integrate ideas or beliefs and actions, and (3) it is a activity that guarantee social order (Bell, 1992: 19-21). Departed from this definition, when ideas or beliefs in society is changed or developed, therefore ritual as action and expression of ideas and beliefs will also be changed. According to Bell (1997), factors that influential in the change of rituals are social transformation, social inventions, and media construction.

\section{B. METHODS}

This research is a qualitative anthropological research using ethnography method with its two main elements, participant observation and in-depth interview. Participant observation is conducted in observing all processes conducted in the nyadran ritual, by attending and participating in the process of the nyadran ritual itself. Participant observation is conducted in two locations in Yogyakarta, Makam Sewu and Imogiri, as the sample locations for this research. Participant observation is conducted to observe the stages in the nyadran ritual, from the beginning to the end. From this observation, all the details of the process of the nyadran ritual, including its requirements and equipments, and prayer recitations, can be known and described in details.

Meanwhile, in-depth interview is conducted to social and religious figures, especially the ritual leaders and traditional or customary leaders in Makam Sewu and Imogiri. From this figures, information regarding all aspects of the performance of the nyadran ritual will be explored. The more specific information the will be explored is regarding the history and development of the performance of the nyadran ritual itself, therefore it can be known what aspects are changed and what other aspects are not changed in the chronological development of the performance of the nyadran ritual. Another important information that will be explored further is regarding to the process of change and development of the nyadran ritual, the possibility of the shift of meaning of the nyadran ritual, and who are the important actors and their roles in the process of the change and development of the nyadran ritual.

KHATULISTIWA: Journal of Islamic Studies Vol. 9. No. 2 September 2019
DOI: https://10.24260/khatulistiwa.v9i2.1478

Change and Development in Nyadran Ritual Tradition in Yogyakarta 


\section{RESULT AND DISCUSSION}

\section{Result}

Makam Sewu and Imogiri have a different history and culture of the nyadran ritual. Makam Sewu is a historical tomb, which was originally a place where Kanjeng Panembahan Bodho or Raden Trenggono was buried. Raden Trenggono was a prince of Mataram Kingdom, where he chose to be a cleric and wandered to spread Islam. However, before he chose to be a cleric, Raden Trenggono was asked to be king in Mataram Kingdom, but he refused. That is why he was called Raden Bodho or Panembahan Bodho. His decision to be a cleric who wandered from one place to another, then he arrived at Kauman village, where he built a mosque for one night only. From his influence and capacity that was considered as "magic", Kanjeng Panembahan Bodho then received his final respect by being buried in the Makam Sewu that located in the Wijirejo village, Pandak, Bantul, Yogyakarta. His tomb is very close to residential areas, therefore the nyadran ritual is always managed and held by local villagers surrounding his tomb.

According to Yadi, a villager who resides near the tomb, the tradition of nyadran ritual itself has been done for long time even before he was born. The tradition is inherited and maintained from generation to generation. It seems that the change and development in the nyadran ritual at Makam Sewu is occurred because of the enthusiasm of the people themselves. Previously, the nyadran ritual was only performed by a few residents of the village, therefore it was not so lively as recent times, where almost all of the residents are enthusiastic to involve and to contribute to the ritual. From 10 sub-villages in Wijirejo village, each 5 sub-villages are chosen alternately to organize the ritual every year. In the procession of nyadran ritual in Makam Sewu, which is always held every Sya'ban month, a month before Ramadhan in Islamic calendar, there are series of ceremonies in the ritual, such as semaan (reciting Quran), pengajian (religious lecture), merti desa (cleaning the village), kenduren (communal feast), the procession of carrying offerings by the villagers dressed in Javanese traditional costumes, and the performance of kethoprak (Javanese traditional drama).

KHATULISTIWA: Journal of Islamic Studies Vol. 9. No. 2 September 2019
DOI: https://10.24260/khatulistiwa.v9i2.1478

Change and Development in Nyadran Ritual Tradition in Yogyakarta 
The parade during the nyadran ritual is so lively, which enlivened by at least 7 parade groups, including the marching band group from "Qurrota Ayyun", a local Islamic school.

Unlike Makam Sewu, Imogiri is the graveyard complex of Mataram royal families and their descendants, from Mataram Kingdom to Surakarta and Yogyakarta kingdom. The first king who is buried in this complex is Sultan Agung, the third king of Mataram Islamic Kingdom. Afterward, the descendants of Sultan Agung are buried in this cemetery, such as Amangkurat, who is the forefather of Yogyakarta Kingdom and Pakubuwono I and II, who are the forefather of Surakarta Kingdom. In this complex, there are the tomb of Hamengku Buwono I - IX from Yogyakarta Kingdom and the tomb of Paku Buwono III to XIII from Surakarta Kingdom. There are total of 24 kings who were buried in this cemetery, from Mataram Islamic Kingdom, Yogyakarta Kingdom, and Surakarta Kingdom. In Imogiri cemetery, there are 8 complex of tomb, consist of 2 complex of Mataram Islamic Kingdom, 3 complex of Surakarta Kingdom, and 3 complex of Yogyakarta Kingdom. This cemetery is managed and maintained by two courtiers from Yogyakarta Kingdom and Surakarta Kingdom. As a consequence, the performance of nyadran ritual is also separate between two kingdoms. The separation of the management, including the separation of the performance of the ritual ceremony between two kingdoms has been prevailed since long time ago. The procession of the nyadran ritual itself is preceded by Surakarta Kingdom, and then followed by Yogyakarta Kingdom. This research is focused to observe the nyadran ritual performed by Yogyakarta Kingdom.

The nyadran ritual at Imogiri performed by Yogyakarta Kingdom is always held on 15 Sya'ban, the month before Ramadhan month in Islamic calendar. The nyadran ritual is performed by abdi dalem (courtier), because there is a belief that the served king himself is not allowed to come to the tomb, therefore he is represented by the abdi dalem. The procession of the nyadran ritual at Imogiri begins with marching uborampe (requirements of ritual) named Kutomoro from Yogyakarta palace to Imogiri cemetery. The uborampe itself contains various kinds of flowers, incense, and other official requirements. Before it is being taken up to Imogiri cemetery,

KHATULISTIWA: Journal of Islamic Studies

Vol. 9. No. 2 September 2019
DOI: https://10.24260/khatulistiwa.v9i2.1478

Change and Development in Nyadran Ritual Tradition in Yogyakarta 
the uborampe is kept for one night in a place called Kadipaten Puroloyo, a village near Imogiri. After being held overnight in Kadipaten Puroloyo, the Kutomoro uborampe is taken to the cemetery by a marching parade consists of several courtiers and royal troops. During the procession of nyadran ritual, courtiers recite prayers to the Lord for the salvation of the royal families buried in Imogiri cemetery.

There is a parade in the procession of nyadran ritual in Imogiri, which only involve courtiers and royal troops. However, this parade is open for the public to witness. Furthermore, for visitors who want to enter the cemetery complex, it is permissible but they are required to follow the rules in Imogiri cemetery, such as using required clothes and should follow other rules. For men, they should use long cloth with bare chests and should use a headband. For women, they are obliged to use kemben, a thick cloth that cover the breasts but the shoulder should kept open. It is free or no cost that should be paid by the visitors to enter the cemetery complex. The important thing is just to follow the rules and to use the required clothes. The visitors may bring and use their own clothes, but if they do not have or do not bring such clothes, they can rent them at the rental counter with the payment of ten thousand rupiah for the rental fee. Another payment is just for donation, by filling the available donation box voluntarily without specific amount.

\section{Discussion}

The procession of nyadran ritual in Makam Sewu is of course driven by its historical and cultural context. As a cleric, Kanjeng Panembahan Bodho had direct and closer relationship with community members, and he was able to raise the awareness of the local residents to honor his meritorious service in his tomb in Makam Sewu. Because of his choice to be a cleric, therefore he was not buried in royal cemetery complex in Imogiri. Instead, he was buried in Makam Sewu, which is an ordinary cemetery in the middle of village settlements, which enable and ease the villagers to honor him in the procession of nyadran ritual. This situation also allows the nyadran ritual to be performed directly by the villagers upon their own initiative. The form of this initiative is by the establishment of an organizing committee to perform the nyadran ritual annually in Wijirejo village based on sub-village alternately.

KHATULISTIWA: Journal of Islamic Studies

Vol. 9. No. 2 September 2019
DOI: https://10.24260/khatulistiwa.v9i2.1478

Change and Development in Nyadran Ritual Tradition in Yogyakarta 
Thus, innovation or invention is possible to be implemented in the nyadran ritual based on the awareness of the villagers themselves. This situation is also related to the context of the life of the villagers that tend to be more religious, which proven by semaan (Quran recitation) and pengajian (religious lecture) during the procession of nyadran ritual.

The direct involvement by the villagers to the procession of nyadran ritual in turn attracts the attention of media because of their enthusiasm to make the ritual to be more enlivened. Various media reported the procession of nyadran ritual, one of them is "Jalan Jogja", an online media, called the nyadran ritual in Makam Sewu as 'cultural tourism'. They said that the nyadran ritual in Makam Sewu is not only a pilgrimage ritual, but it is already changed into cultural tour, because of the great number of visitors who come not only from around the village, but they come from outside the village and even attended by tourists from abroad. They come by a number of buses that filled the road, which in turn it also makes the nyadran ritual in Makam Sewu is more enlivened and more known as annual cultural event that attract more people to come. In addition, the procession of nyadran ritual in Makam Sewu is also supported by the local government, in the form of allocating aid from village aid fund. In addition, Yadi said that there was a special fund from provincial government (dana keistimewaan DIY) that intended to be allocated to support the procession of nyadran ritual in Makam Sewu, but they should establish a special committee that capable to manage it.

If the nyadran ritual in Makam Sewu has a lot of influence from villagers and the media, then the nyadran ritual in Imogiri tends to be conservative, which is to minimize the involvement of surrounding people and the media. The conservative situation at Imogiri is shown by the description of the head of the courtier in Imogiri, who said that the Sultan and the Queen even are not allowed to go to the cemetery complex during the nyadran procession. The procession of the ritual should be handed over the courtiers. The public in general are also not allowed to take part and to be involved in the procession of the ritual, which makes the ritual to be very conservative from the past until recent times.

KHATULISTIWA: Journal of Islamic Studies

Vol. 9. No. 2 September 2019
DOI: https://10.24260/khatulistiwa.v9i2.1478

Change and Development in Nyadran Ritual Tradition in Yogyakarta 
If the local people want to participate in the nyadran ritual in Imogiri, then they should become courtier first. This requirement actually happened in Imogiri where many local people are appointed as courtiers by following the footsteps of their parents. The restriction in the nyadran ritual in Imogiri cannot be separated from the role of the courtiers and royal troops, who keep and maintain the ritual is restricted for the public. However, the government still have its role of exists in the nyadran ritual in Imogiri, which originated from the Yogyakarta palace through the cultural service board, especially in financing the procession of the ritual and for the maintenance of the Imogiri cemetery in general.

From the observation conducted in two locations, change and development of the nyadran ritual occurred in Makam Sewu, but it did not occur in Imogiri. It can be seen from the nature of nyadran ritual itself in each place, where the nyadran ritual in Makam Sewu is open, can be attended by the public in general, while the nyadran ritual in Imogiri is closed, cannot be attended and followed by the public; people are only 'spectators' in the ritual procession. Media coverage is also intensive in reporting the nyadran ritual in Makam Sewu, because of the openness of the ritual, while in the nyadran ritual in Imogiri, media cannot report it because the nature of the ritual is closed for the public. The public's enthusiasm is very high in attending and participating in the nyadran ritual in Makam Sewu, because it is supported by intensive information from the media, while information about the nyadran ritual in Imogiri not widely known by the public, because it is not covered by media.

Based on this fact, it can be inferred that the main cause of the change and development of the nyadran ritual is the nature or the characteristic of the ritual itself. In Makam Sewu, the characteristic of the nyadran ritual is open for public, which provides an opportunity for the community, both the community surrounding Makam Sewu and the community from outside Makam Sewu area to be involved in the procession of nyadran ritual. As a result, changes and developments are possible in various parts of the ritual, in line with the development of the community involved in the ritual. Meanwhile, the characteristic of nyadran ritual in Imogiri is closed for public, so that it automatically closes the opportunity for change and development.

KHATULISTIWA: Journal of Islamic Studies

Vol. 9. No. 2 September 2019
DOI: https://10.24260/khatulistiwa.v9i2.1478

Change and Development in Nyadran Ritual Tradition in Yogyakarta 
The nyadran ritual in Imogiri can only be carried out by courtiers and royal troops with very strict orders and rules from Yogyakarta palace. With this situation, of course the opportunity for change and development are more likely to take place in the nyadran ritual in Makam Sewu, and almost never take place in Imogiri.

When looking at the actors involved and their role in the procession of nyadran ritual, the modifications that occur in the nyadran ritual in Makam Sewu seem to be caused more by the involvement of the people from outside Makam Sewu and from the intensity of the report and media coverage. The enthusiasm of the people to witness and to be involved in the nyadran ritual in Makam Sewu is like a snowball roll, where people who have been involved or witnessed will invite and take their relatives and acquaintances to participate in watching or even involving in the nyadran ritual in the next year. Intensive media report and coverage also can be a means of persuasion and stimulating the people to participate and to witness the nyadran ritual in Makam Sewu, where they framed the nyadran ritual in Makam Sewu Tomb as cultural tour. Meanwhile, the courtiers as the committee who hold the nyadran ritual in Imogiri, at the same time they play a role in maintaining the exclusivity of the nyadran ritual they carried out. It also means that they play a role in preventing changes or modifications that may happen to the nyadran ritual in Imogiri. In this case, cultural conservation is highly maintained to prevent changes and modifications in the nyadran ritual in Imogiri.

Departed from this fact, the change and development that occur in the nyadran ritual at Makam Sewu are in line with Bell's (1997) theory of ritual change, which at least include three things: social transformation, invention or renewal, and media construction. Changes that took place in the nyadran ritual at Makam Sewu is a form of renewal, which is carried out by local people such as cultural parade that had previously only been carried out by a few people, then now it involves more people, including children. Media construction also have contribution in the change of the nyadran ritual, which made this tradition is more known by wider public, and in some cases they make commodification to the nyadran ritual in Makam Sewu by inviting sponsors for their program. Meanwhile, the nyadran ritual at Imogiri does not change, because of its characteristic that closed for public, and the role of the actors, which is the courtiers, who keep preventing the nyadran ritual at Imogiri from changes.

KHATULISTIWA: Journal of Islamic Studies Vol. 9. No. 2 September 2019
DOI: https://10.24260/khatulistiwa.v9i2.1478

Change and Development in Nyadran Ritual Tradition in Yogyakarta 


\section{CONCLUSION}

From the description above, it can be concluded that change and development occurred in the nyadran ritual in Makam Sewu, but in Imogiri, change and development did not occur. This is mainly because of the character of nyadran ritual in Imogiri is exclusive and closed for the public, while the nyadran ritual in Makam Sewu is inclusive, opened, and even involving the public. The villagers who reside in surrounding Makam Sewu also make their contribution to the change and development of the nyadran ritual in Makam Sewu, especially by managing and making it open for the public, and making it more enlivened, which in turn it will attract more people to come to witness it or even to be involved further in the nyadran ritual in Makam Sewu.

The process of change and development of the nyadran ritual in Makam Sewu is come more from external factors, especially from the enthusiasm of the wide public to witness and to be involved further in the ritual. The media construction is also influential, with the coverage of the nyadran ritual in Makam Sewu by various media, such as television, print media, and online media, which makes the nyadran ritual in Makam Sewu is more known for wider public. Meanwhile, the internal factors in Imogiri, mainly the obedience of the courtiers in maintaining the tradition of making the nyadran ritual closed for the public is very influential, which makes no significant change and development in the nyadran ritual in Imogiri.

KHATULISTIWA: Journal of Islamic Studies Vol. 9. No. 2 September 2019
DOI: https://10.24260/khatulistiwa.v9i2.1478

Change and Development in Nyadran Ritual Tradition in Yogyakarta 


\section{BIBLIOGRAPHY}

Baskara, Benny. 2012. Commodification of exotic culture: the case of the Bajo in Wakatobi Islands, South East Sulawesi. Proceeding of the $4^{\text {th }}$ IGSCI. Yogyakarta: Universitas Gadjah Mada.

Bell, Catherine. 1992. Ritual Theory, Ritual Practice. New York: Oxford University Press.

Bell, Catherine. 1997. Ritual: Perspectives and Dimensions. New York: Oxford University Press.

Fealy, Greg. 2008. Consuming Islam: commodified religion and aspirational pietism in contemporary Indonesia. In Fealy and White (eds.) Expressing Islam: Religious Life and Politics in Indonesia. Canberra: Institute of Southeast Asian Studies.

Gotham, Kevin Fox. 2002. Marketing Mardi Gras: commodification, spectacle and the political economy of tourism in New Orleans. Urban Studies Vol. 39 No. 10, December. London: Sage.

Kusumawati, Aning Ayu. 2013. Nyadran sebagai realitas yang sakral: perspektif Mircea Eliade. Thaqafiyyat Vol. 14 No. 1. Yogyakarta: UIN Sunan Kalijaga.

Mertamupu, I Ketut. 2012. Ritual Nyadran Berasal Dari Tradisi Veda. Artikel dalam [www.kompasiana.com]. Diakses tanggal 25 Mei 2019.

Pieris, Aloysius. 1988. An Asian Theology of Liberation. Maryknoll, New York: Orbis Books.

Purwaningsih, Ernawati. 2017. Tradisi nyadran tuk tempurung dari domestik ke publik. Patrawidya Vol. 18 No. 3, Desember. Jakarta: Depdikbud.

Shepherd, Robert. 2002. Commodification, culture and tourism. Tourist Studies Vol. 2 No.2. London: Sage.

Sinha, Vineeta. 2011. Religion and Commodification: Merchandizing Diasporic Hinduism. New York: Routledge.

Xie, Philip Feifan. 2003. The bamboo-beating dance in Hainan, China: authenticity and commodification. Journal of Sustainable Tourism Vol. 11 No. 1, March. London: Routledge.

KHATULISTIWA: Journal of Islamic Studies Vol. 9. No. 2 September 2019
DOI: https://10.24260/khatulistiwa.v9i2.1478

Change and Development in Nyadran Ritual Tradition in Yogyakarta 